\title{
Trpljenje nedolžnih in iskanje besede (od)rešitve v dramatiki Stanka Majcna
}

\author{
KAREL GRŽAN \\ Sladka Gora 11, SI-3240 Šmarje pri Jelšah, grzank@gmail.com
}

SCN II/2 [2009], 114-128

\begin{abstract}
Prispevek je prikaz soočanja Stanka Majcna s trpečimi, ob katerih se čuti osebno poklican k dejavnemu premagovanju bolečine nemočnih. Kot družbeno ujet človek tega ne zmore - ostaja na poziciji zavarovanih. Njegovo orožje so le besede, s katerimi drami »revolucijo«. Razkorak med besedo in dejanji budi v njem razpetost in neuresničeno čutenje življenja.
\end{abstract}

This article analyses the presentation of human suffering by Slovene dramatist Stanko Majcen, who felt personally called to actively overcome the pain of the helpless. Ironically, as an individual, he felt imprisoned by his position in society; which prevented him from personal engagement with the oppressed people with whom he identified, so long as he remained in the position of the protected. His weapon was words alone, which he used to try to awaken a "revolution". The gap between words and actions, however, made him feel as though he were stretched, and ultimately he felt that his life was unfulfilled.

Ključne besede: Stanko Majcen, dramatika, trpljenje, odreševanje

Key words: Stanko Majcen, drama, suffering, redemption

\section{Iz zlate dobe varnosti v izkustvo trpljenja}

Stefan Zweig (1958) opisuje čas Evrope pred začetkom prve svetovne vojne kot zlato dobo varnosti. V skoraj tisočletni avstrijski monarhiji je bilo videti, kot da je vse zgrajeno na trajnih temeljih in da je država sama najvišji porok te stabilnosti. Avstrijska krona je krožila v zlatnikih in dajala poroštvo za svojo stabilnost. Vsakdo je vedel, koliko ima, koliko mu pripada, kaj je dovoljeno in kaj prepovedano. Varnost je bila resda najprej privilegij premožnih ljudi, postopoma pa je postajala tudi del širokih ljudskih množic. Delavci so si izbojevali ustaljene mezde in bolniške blagajne. Na socialnem področju je bil viden 
napredek: iz leta $\mathrm{v}$ leto je posameznik dobival nove pravice, beda množic se ni zdela več nepremagljiva. Sociologi in znanstveniki so tekmovali, da bi pomagali proletariatu do čim bolj zdravega in srečnejšega življenja. »Ali je torej čudno,« se sprašuje Zweig,

.... če se je to stoletje oplajalo z lastnimi uspehi in občutilo vsako končano desetletje samo kot stopnjo v novo, še popolnejšo dobo? V povratek barbarstva, kot so vojne med narodi Evrope, so ljudje prav tako malo verjeli kot v čarovnice in strahove. Naši očetje so bili trdno prežeti z zaupanjem v zanesljive vezi strpnosti in sporazumevanja. Odkritosrčno so mislili, da se bodo polagoma odstranile meje in nesoglasja med narodi in verami in da bo vse človeštvo doseglo najvišji dobrini: mir in varnost. (Zweig 1958: 23-25)

Ta zlata doba varnosti pa je bila le videz, ki se je drobil v realnih podobah sveta, še posebej v realnosti prve svetovne vojne.

Stanka Majcna so vznemirjala razmerja v družbi (Kocjan 1990: 88). Koblar (1939) izjemno zanimivo opisuje njegovo vpetost v ta čas, ki najde izraz v njegovem literarnem ustvarjanju. Za zadnji rod pred prvo svetovno vojno Koblar pravi, da:

... kaže že v svojem začetku izrazite idealistične prvine; najprej je sicer nekoliko sledil novoromantičnim razpoloženjem, vendar vidimo, kako v vsem čuti drobečo se celoto človeka. Zato je tudi začel razkrajati življenje v prvine in je vnovič iskal pod krinko videza in laži pravo človeško podobo. Nova umetnostna gesla so ta rod tudi napotila v iskanje novega izraza, zato je prevzel nase naloge iskalcev in oznanjevalcev ter je najgloblje občutil polom starega človeka ob vojski. Med njimi je najostrejši duševni raziskovalec in videc Stanko Majcen, sodnik vojne spačenosti. (Koblar 1939: 264)

Stanko Majcen, ki ga Zorko Simčič (2000) opisuje kot bolestno občutljivega, Slodnjak pa kot »ostrega analitika« (Slodnjak v Schmidt 1997: 310), je bil v dunajskih letih (1908-1911) vpet v upanje »zlate dobe varnosti« (n. d.), obenem pa vedno znova prizadet ob soočanju s konkretnim človeškim (in ne samo človeškim) trpljenjem. Ni zmogel brezbrižnosti, ki jo izraža v črtici V točilnici: »Da se le spi, nesreča pa ... zunaj pusti,« kajti kot piše v nadaljevanju: »Burja pa ni odnehala, zdelo se je, da narašča od ure do ure.« (N. d.: 25). Bolečina posameznikov ga je vznemirjala, nagovarjala, izvzetega privilegiranemu družbenemu statusu. Ta izvzetost, zavarovanost je v njem samo še poglabljala napetost, ta pa je budila in burila njegova razmišljanja in iskanja, predvsem pa usmerjala njegovo razmišljanje k spoznanju o potrebnosti osebnega vstopa v konkretno bolečino soočloveka. Samo po tem osebnem vstopu v nično točko sočloveka lahko doseže odrešenje.

Marja Boršnik pravilno ugotavlja, da »Majcen kakor Dostojevski rad brodi po človeškem dnu, pa bi dvomili, da tam ni iskal svetlobe« (Boršnik 1967: 380). Denis Poniž piše, da je Majcnov »izraz ekspresivno zelo močan, poln emocije in vitalne sile, zgoščuje se v vizijo stiske in trpljenja« (Poniž 1990: 44). Ta stiska, to trpljenje prebuja v njem konfliktnost do družbenega in spoznanje, da ostajaš v tem svetu kakor sam s svojim osebnim poslanstvom, zaradi katerega te je, kot pravi v Profesor Gradniku razvoj na svet poslal (Majcen 2001, 71). 
Dejstvo trpljenja je tako očitno, da bi se morali, če se z njim ne bi hoteli soočiti, umakniti, tako kot puščavnik v njegovi črtici Klic, na samotni otok prirejenega življenja. A to ni mogoče, ker bi nas slej ko prej obiskalo. »Jaz sem človeštvo in te pridem obiskat.« (N. d.: 32). Malokopka v Ženinu na Mlaki spregovori: »Od vsepovsod drži pot na mlako.« (N. d.: 922).

Majcen uporablja izraz mlaka, blato za konkretno/e stisko/e drugega in širši prostor; dežela te stiske je Mlaka, ki kot v krču kliče po odrešenju. »Svet se lomi pod nogami ko brod v viharju: zdaj ga ni, zdaj se skopiči do neba.« (n. d.: 917), pravi v isti drami. Francelj, sluga kraljevega namestnika Vrhovljana; v drami Cesar Janez opiše poti sveta: »Zlato je kalno od vlage - kaj morem! In hlačnice so oblatene. I.../ Hrib za hribom in še za tretjim hribom hrib, in vse v brozgi do kolen. V Negovi smo mislili, da bomo utonili v blatu.« (N. d.: 135). Duhovnik Martin v drami Čudež govori: „Ceste so v blato vgreznjene, truden sem.« (N. d.: 247)

Po soočenju s fronto prve svetovne vojne piše Majcen pismo Izidorju Cankarju (št. 5):

Vojska je velik ventil, skozi katerega se izlije smrad in gniloba stoletja. Ljudje sami spoznajo, da je blata in brozge že previsoko, zrak prepoln kužne zlobe in zatohle ničvrednosti in si sami odprejo tak ventil. I.../ Tudi žalost je že postala bolezen, ki si sama sebi koplje rov skozi celice telesa in brizga strup v kri. (Majcen 2001: 25)

Čeprav je bil Majcen samotar, je morda prav zato v svojem doživljanju globoko zaznaval bolečino sveta. V njegovi črtici Klic teče beseda o samotarju, ki na pustem otoku živi brez vznemirjanja in se »ohranja srečnega«. V to življenjsko situacijo, ki jo označuje, da je »daleč od ljudi sredi valov morja na samotnem otoku«, kar nenadoma trešči:

A nekoč ga je obiskalo. Prišlo je čez morje do njega in potrkalo. In je prestopilo prag in bilo sključeno in nagubano kakor sto let staro. Dolgi sivi lasje so viseli kakor mah z glave in tanke srebrne trepalnice so trudno ležale na licih. S koščeno roko, oprto na palico, je s težavo prestavljalo noge. (N. d.: 32)

Tisto, kar se je pojavilo, ostaja neznano kot subjekt, je nekaj, kar nima obličja, iz konteksta pa se vidi, da je usodna sila, ki bo pretrgala dotedanjo idilo. Prav takšne sile se v okviru književne avantgarde že dolgo imenujejo Neznani Nekdo. Ta miselna kategorija ostane v veljavi tudi še potem, ko se gost razkrije kot človeštvo. (Pogačnik v Schmidt 1990: 73)

Ana Marija Golar, ob kateri zgodba poteka, zjutraj dejansko najde pred vrati zmrznjenega človeka. Pod oknom leži mrtev človek, kdo ve od kod in kdo ve kam namenjen, z licem naslonjen na borno kočo (Majcen 2001: 33).

Kdo je ta Neznani Nekdo, z licem naslonjen na njeno kočo? Njegov obraz je neprepoznan. Je človek, ki ga moraš v njegovi stiski prepoznati sam, vstopiti v njegovo bolečino, v kateri boš našel odrešenjsko možnost njegovi in svoji bolečini. 


\section{Iskanje (od)rešitve}

Majcnovo temeljno vprašanje je: »Zakaj trpijo nedolžni?« V mnogočem obvarovan pred trdoto življenja se nenehno sooča $\mathrm{z}$ dejstvi bede in s hladno brezbrižnostjo tistih, ki so iz nje izvzeti. Njega trpljenje preveč nemočnih vznemirja, da bi lahko molčal, da bi ne protestiral. V enodejanki Profesor Gradnik izpoveduje:

Oprostite, da pri tej priliki nekaj pripomnim, česar ne morem zamolčati. Beda: glad, pomanjkanje v velikem mestu - je fizična bolečina, gotovo. To ni poglavitno. Poglavitno je, česar se v bedi ne osveščaš. Mislim izteče kri, nazorom zmanjka tal, vse obvisi v zraku. S strastjo se poženeš v razne teorije, tolmačiš prikazni s stališč, na katerih zdrav in čil razum nikoli stati ne more. Trudoma pridobljena spoznanja pretiravaš, brez potrebe se vnemaš za odkritja, ki te nič ne brigajo. Revolucija, revolucija, revolucija ti gomazi po glavi. (N. d.: 71-72)

Ta notranji upor ob soočenju s trpljenjem je v Majcnovi zunanji uglajenosti težko prepoznan, pa vendar je očitno izražen v njegovih dramah - njegovem videnju odreševanja niča.

\section{Majcnova zavrnitev možnosti odrešitve po družbenem}

Majcnove drame so začele nastajati med najhujšimi svetovnimi pretresi, ko so umetniki iskali nove oblike umetnosti in ko so različne revolucionarne skupine propagirale vsaka svoj načrt družbene prihodnosti. Majcen je poznal ta družbena valovanja, a je do vseh ohranjal osebno odmaknjenost. V črtici Nevernik zapiše: »Živeti treba, umreti treba za domovino, a jaz ne morem ne živeti, ne umreti ... za domovino ...« (N. d.: 124)

Kermauner ugotavlja, da je »Majcnovo razmerje do politike zamotano. Gre za radikalno kritiko slovenske predvojne družbe. Kar veliko pove, če jo izreka bivši podban. /.../ Takšna (ob)sodba ima posebno moralno in intelektualno težo, saj je bil Majcen vrhunski intelektualec." (Kermauner 1992b: 244). Majcen v svoji dramatiki kritizira in smeši dejansko vse vodilne dejavnike javnega življenja v njihovi izrojenosti.

Majcnova dramatika bi mogla biti po tej plati celo realistična, saj zajema socialno razrednoplastno zelo široko paleto od nemško-avstrijskih plemičev in slovenskih oficirjev, mednarodnih novinarjev, srbskega meščanstva itn. v Kasiji; od nemško-avstrijske uradniške aristokratske oblasti, a enako lumpenploretarcev, konjedercev, otrok v Dedičih; prek inženirjev, kmetov, župnikov, delavcev, učiteljev, koliščarjev, državnih uradnikov $v$ Prekopu; do profesorjev, popov, najrazličnejših poklicev v Apokalipsi; različno $v$ hierarhijo uvrščenih duhovnikov, kmetov, obrtnikov v Mehu; trgovcev, spet duhovnikov, pastiric, obrtnikov v Sveči; do študentov, univerzitetnih profesorjev, služkinj v Revoluciji - komaj kakšen poklic ni upoštevan. (Kermauner 1992b: 245)

Majcen ni bil oseba, ki bi družbene institucije rušila ali jih zapuščala. Prav presenetljivo je v njih dejavno sodeloval. Vendar pa si je dovolil, da je v dramah (in morda res le v dramah) videl sebe drugače in se je resno spraševal o svojih 
zmožnostih, o tem, kako lahko sam sebe ustvarja in se predstavlja. Majcnov sodobnik Jakob Levy Moreno je zapisal:

Staro scenarijsko knjigo vrzi proč. Delaj po novem, tu in sedaj. Igraj samega sebe, takega, kakor nisi bil še nikoli. Potem morda lahko začneš biti tako, kot bi ti lahko postal. Dovoli dogajanje! Bodi sam sebi inspiracija, poet, predstavljaj samega sebe, bodi sam sebi terapevt in končno tudi stvarnik. (Moreno v Stritih 1996/97: 100)

Z vso resnostjo se je Majcen spraševal, kako naj neha biti družbeni produkt in kako začeti biti sam svoj stvarnik (prav pomenljivo se v Revoluciji tako tudi poimenuje: profesor Stvarnik), vendar ne tako, da bi pretrgal dialog z družbenim. V družbenem je razbiral zakonitosti njenega delovanja, obenem pa iskal prebujene posameznike (v drami Revolucija sin Vanja), ob katerih je lahko spoznaval svojo usmerjenost. Majcen je s svojim življenjem kazal, da je kulturno tisto življenje, v katerem posameznik namesto gotovosti ponavljanja vzame nase negotovost trenutka in zaživi kot človek, s tem da prevzame svoj del odgovornosti. Temeljno Majcnovo iskanje se je dogajalo v okviru zanj najpomembnejšega vprašanja, ko se ob trpljenju posameznika sprašuje o odreševanju.

\section{Majcnova paradoksalna življenjska situacija}

Stanko Majcen je kot veliki kritik družbenega izjemno močno ujet v družbeno, podružbljeno. "Paradoks je, da je bil prav Majcen zgleden državni uradnik, podban Dravske banovine. A se je v času svojega uradništva, ki je trajalo skoraj četrt stoletja, odpovedal pisanju umetnosti. Bil je skrajno dosleden.« (Kermauner 1992a: 225). Kljub osebnemu odporu se ni zmogel upreti toku dogodkov, ki so ga vpeljali v politično življenje. Izidorju Cankarju zaupljivo piše (pismo št. 2):

Meni pripravljata oče in stric (kanonik in ud dež. šol. sveta) te dni pot v politično službo. Ime Majcen je v uradnih štajerskih krogih dobro znano in tako ni nič ovir. Da grem jaz tako rad, kakor me radi sprejmejo, bi bilo vse v redu. A mene stane premagovanja in samozataje. Ti ne boš nikdar služil, služil namreč tako, da bo s Tvojim imenom zvezan pojem instance, poosebljen red in avtoriteta. In vidiš, to je najhuje. Zapovedovati drugim in sebi ne moči reči besedice brez bolečine. Naj bo, kaj bo, če bo - pravijo loterijke, pa se še mene loti vratolomnost, srčnost igre. (Majcen 2001: 18)

Biti nad je bila za Stanka Majcna »bolečina«. Njegovo mesto, kot ga je doživljal v skladnosti svojega jaza, je bil položaj v. Majcen ostaja nad v prizadevanju, da bi ustvarjal juridično območje pravičnosti. Vendar tudi ob tem spoznava nemoč in doživlja razočaranje. V Spominskem zborniku Slovenije za leto 1939 kritizira tedanjo policijsko in administrativno-sodno prakso, že pred tem pa v Slovencu (25. april 1936) izraža zavest svojega pogosto sizifovskega uradniškega dela:

Vse daješ in delaš, ne zaleže pa nič. Snuješ, oblikuješ, pa ti prečrta račune čas s svojimi nepredvidenimi zahtevami. /.../ Pesimizem, prepuščanje samega sebe in svojega dela usodi, je čest pojav med upravnimi delavci. I.../ Prilike, ki v njih živimo in ki jih nismo 
zakrivili, so take, da komaj utegnemo misliti na svojo glavno nalogo, na svoj civilizatorski poklic; ne moremo trošiti časa, sil in sredstev za duhovni in materialni napredek, ko gre za to, da se rešuje golo življenje. (Majcen 1939: 136)

Čas je Majcnu prečrtal vse dobre namere. Italijanska okupacija ga je postavila v popolno nemoč, samovolji nemške oblasti pa ni mogel slediti, zato ga je ta 30. junija 1944 upokojila.

Kermauner razmišlja o njegovi situaciji:

Morda je bil Majcen vendar preveč visok uradnik, odvisen od položajev in služb, ki jih je zavzemal, od stranke in strani, ki ji je pripadal ali ostajal zvest, od ljudi, ki so ga ščitili, od institucionaliziranega slovenstva, ki ga je oblikoval v državnopravno formo, skratka od tega sveta, naj je bil še tako distanciran od kulturnega in dobesedno političnega in družbenega življenja. (Kermauner 1990: 132)

Dimitrij Rupel (1990: 161) ga uvršča celo med »neke sorte dvornega pisatelja«. Ob njegovem pisanju o Antonu Korošcu označuje Majcna »kot zanesenega in do neke mere naivnega pisatelja. I.../ Takšen tekst ( $\mathrm{tj}$. Majcnovi spomini na Korošca, op. p.) spada med značilne hagiografske spise, med pritikline režima, ki nastopa v omenjeni svetosti in slavi. Značilno režimsko pisanje torej!? « (N. d.: 161)

Kakor koli, dejstvo je, da je bil Majcen resnično sredi družbenega dogajanja, na neki način celo »dvorni pisatelj« zakonov, protokolov ... Prav uvid v to dogajanje pa mu je omogočil tudi notranji odmik. Bolj ko poznamo zakone sveta, svobodneje se lahko v tem svetu gibamo. Izgubimo se lahko le v okolju nepoznanega. Majcnovo temeljno poznavanje družbenega delovanja mu je ob notranjem odmiku omogočilo osvoboditev in analizo. Ostaja sredi družbenega, a ga v sebi in v izrazu svojih dram notranje že zapušča in preizkuša iskanje novega, bolj odrešenega sveta.

Gledališče je del procesa stvarjenja, del svete igre sveta. I.../ Svet se nam torej kaže kot igra pogledov in videzov. A kdor misli, da se lahko s posnemanjem videza neodgovorno igra, s tem prezre črto, ki omejuje področje, kamor se angeli bojijo stopiti. Igra pogledov in videzov tvori in proizvaja življenje, zato ni v naših rokah, ampak se dogaja. (Stritih 1996/97: 93)

Veliko vprašanje je, kako bi teklo Majcnovo življenje, če ne bi našel tega dogajanja in ga izražal v dramah, predvsem v zadnjem obdobju življenja, ko mu je tudi ironizacija sredi blodnje podružbenega omogočala preživetje. Kot piše Kermauner: »Prevajal je mistične knjige in hodil mnogo k obhajilu. Zaradi nizke pokojnine si je omogočal fizično preživljanje z gojenjem zelenjave, ki sta jo z ženo prodajala na trgu. Bivši podban je torej tudi živel groteskno; a očitno v stoičnem samoposmehu.« (Kermauner 1992b: 244)

Ob spoznanih principih družbenega delovanja je Stanko Majcen nenehno doživljal in preverjal svoj status, mesto in svojo dejavno uresničenost v odreševanju niča. Čutil se je osebno poklican za to, a je bil zaradi brezobzirne grobosti sveta nemočen za dejavni vstop v konkretno nično točko. »Svojo ranljivost prikriva z držo odmaknjenosti, kakor da se ga dogajanje krog njega ne 
tiče; a ta navidezna izolacija je le obramba pred brezobzirnostjo in nasilnostjo sveta.«(Glazer 1990: 60). V svojem konkretnem življenju je ostajal zunaj nične točke, na njenem robu le opazovalec, analitik, močno povezan z družbenim, kot ugotavlja Dimitrij Rupel (1990: 153): »Gre za avtorja, ki je imel v slovenski in jugoslovanski oblastni strukturi izjemno visok položaj.«

\section{Moč duha in nemoč dejanj}

Majcen se je bal tveganja. Ob močnem duhovnem doživljanju je ostajal v svojih dejanjih nemočen. To je izrazil v že navedeni enodejanki Profesor Gradnik, ko ta doživlja svojo nemoč za dejaven vstop v konkretno živo življenje, ki bi ga potegnilo v nepredvidljive razsežnosti oceana življenja. V drami Cesar Janez pripoveduje:

Revolucija je v nas vseh, sva rekla. Svobode si želimo vsi, krvavo si je želimo, pa makar krvave svobode. I.../ Gre le za to, ali bo to svoboda trebuha ali svoboda duha. Če svoboda trebuha, smo zgubljeni, če svoboda duha, smo stopili korak dalje v neznano bodočnost, kjer nas čaka nov prelom, dokler nas ne bo zadnji prelom prelomil za neko bivanje brez prelomov. /.../ To je moja filozofija. (Majcen 2001: 193)

Gre za dejavno vključenost v razvoj. Zanj sta otrebni tveganje in dejanje, kot pravi tudi Stvarnik v Revoluciji: »Prav tveganje je tisto, kar miče; kar dosežěs, vselej razočara« (n. d.: 68).

Vendar Majcen ne zmore odločilnega koraka, ker ga je strah; ne zmore koraka v drugo, drugačno, kot beremo v Bogarju Mehu in Mariji:

Meho: Strah me je.

Miholjka: Pred menoj?

Meho: Ni me strah pred teboj, vsega me je strah. Od groze bom umrl. (N. d.: 444)

V tej drami očitno izraža, česa ga je strah: »Strah me je, groza me je - čuj! (Topot množice, mrmranje, pretenje, klicanje na korajžo ...)« (n. d.: 445). Boji se nepredvidljivosti reakcij množice (primerjaj z zaključkom drame Revolucija).

Tudi ko je Majcen svojo »revolucijo« izrazil samo z besedo, ga je strah odziva nanjo. Med premiero drame Kasija 15. oktobra 1919. leta je sedel v gostilni pri Lovšinu (Schmidt 1990: 213), kasneje pa je previdno spraševal, kako je bilo sprejeto sporočilo te drame. Hinku Nučiču ${ }^{1}$ je v pismu napisal (št. 1):

Zdaj, ko sem Kasijo videl v Ljubljani uprizorjeno, Vas moram prositi, da te stvari $v$ Mariboru ne igrate. Razlogov bi lahko naštel 10. Navideznih še več. Mislim pa, da Vam kot prijatelju smem razodeti tistega enega, ki je zame najtehtnejši. Moj vprav smrtni strah pred premiero $v$ Ljubljani. (Majcen 2001: 76)

${ }^{1}$ Hinko Nučič je bil leta 1919, ko mu Majcen piše to pismo, umetniški in organizacijski vodja nove slovenske kulturne ustanove, igralec in režiser. 
Dve leti kasneje mu je v pismu (št. 2) zaupal, da Kasije ni videl, »saj je še v Ljubljani nisem šel gledat. Imejte to za posebnost mojega značaja, za bojazen, pogledati samemu sebi v oči.« (N. d.: 77)

»Značilno za Majcena pisatelja pa je to, da se popolnoma skrije za dogajanje« (Majcen 1995: 270), ugotavlja Goran Schmidt. Ko je napisal drame Ženin na Mlaki, Brez sveče, Revolucija ..., jih je spravil v predal. Dimitrij Rupel (1990: 154) se sprašuje, »kakšna je narava kritike, ki leži v predalu; ki nastopi javno življenje po avtorjevi smrti«.

\section{Beseda kot orožje}

Stanko Majcen se ni čutil dovolj močan, da bi stopil v konkretno dejanje. Vendar je bilo njegovo notranje doživljanje tako močno, da ga je na neki način moral izraziti. Beseda je postala njegovo orožje. V drami Revolucija pravi Stvarnik: "Zajel bom vse to gibanje, pretočil ga v epruvete, analiziral, udaril nanje pečat svoje misli, svojega iskanja.« (Majcen 2001: 84) Majcnov upor, njegova »revolucija« se je dogajala po njegovi literarni besedi. Ta je bila samokres, s katerim je streljal in potem (skrit v sosednji gostilni) opazoval in spraševal o njegovem učinku.

V Kasiji pa beremo besede Ivančiča:

Te dobrodelne prireditve so že pravcata nadloga. Bes jih lopi! Družba bi se rada videla, to je. Generalka je dobila novo obleko, občudujte generalko v novi obleki! /.../ Do grla mi sega to življenje. Mora se najti beseda, ki o pravem času sprožena udari mednje kakor strela. Te poslikane, voščene, strnjene obraze bi videl osvetljene od strahu in nepopisne groze, groze nenadnega spoznanja. Mora se najti beseda. Pesnik je ne bo našel nikoli. Do krvi prebičan proletarec jo bo našel. I.../ Sicer pa dosežem isti učinek, če v tole družbo sprožim samokres. I.../ Tako za poskušino namreč. Ženske bi omedlele, kajpak. Ali moški, kaj bi moški? Moške bi si ogledal zapored, natanko in od blizu, naravnost $v$ oči bi jim pogledal. (N. d.: 30)

Majcen si je želel, da bi s svojimi idejami razbijal okostenelo zlaganost časa. »Ali niso to ideje, ki naš čas bijo po zobeh,« piše v pismu Francetu Koblarju (št. 6) (Majcen 2001: 82). Vendar pa ni njegovo poslanstvo v »demonstrativni priključitvi v vrsti«. Po Stvarniku v drami Revolucija razloži:

Že samemu se mi je navrgla misel, da bi šel in se demonstrativno priključil. Stopil v vrsto, bil eden od njih. Pa mi ni, pa ne morem. Prelomil bi vero, ki jo imam vase. Mar nisem glasnik duha in kaj ima duh opraviti $z$ 'demonstrativno priključitvijo', z vrsto, ki stoji tam kot cinasti vojaki? (N. d.: 84)

Zato: »Zajel bom vse to gibanje, pretočil ga v epruvete, analiziral, udaril nanje pečat svoje misli, svojega iskanja.« (N. d.: 84)

Tako je utemeljil svoj »revolucionarni« položaj Majcen, vendar se z njim ni nikoli sprijaznil. V isti drami prikaže neučinkovitost besede (ki dosega pri množici nasprotni učinek) in z Vanjevim korakom potrdi pravilnost dejavnega vstopa v nične točke življenja. Samo tako (pa čeprav po smrti) je možen vstop 
v nove razsežnosti, je dosežen razvoj, zaradi katerega smo bili poslani na svet (primerjaj z dramo Profesor Gradnik, n. d.: 72). Leta 1961 je pisal pismo Bogi Pretnar-Dajdici (št. 2): »Včasih sem žalosten, veš, in tedaj mi ni za ves svet. Ni to kaka literarna žalost, iz papirja za papir, temveč tisti pravi obup, ko človek čuti, da ni živel prav, da se mu izteka življenje in da ne more popraviti nič več ...« (Majcen 2001: 114). V enem od naslednjih pisem (št. 4) jo je opogumljal: »Ljuba Dajdica moja, ne zavrzi se! Vseeno je, kdo Ti je poklonil te darove - neguj jih, rabi jih, izkoriščaj jih!« (N. d.: 119)

\section{Iskanje besede}

Romano Guardini, katerega misli so bile izziv Stanku Majcnu, je napisal, da je govorica:

... smiselnostni prostor, $v$ katerem živi vsak človek. Je takšna povezanost smiselnostnih likov, ki jo določajo nadindividualne zakonitosti, posameznik se vanjo rodi in ona ga oblikuje. Govorica je nasproti posamezniku neodvisna celota, ob kateri posameznik po meri svoje obdarjenosti nekaj oblikuje. Človek eksistira v tem svetu smiselnostnih likov. Kakor pravi Heidegger, šele govorica daje "možnost stati sredi odprtosti bivajočega". Tako je govorica objektivni temelj za to, da pride do osebnostnega srečanja. (Guardini 1991: 86-87)

Beseda je Stanku Majcnu najvišji kriterij vsakršne življenjske izjave. V drami Revolucija išče Stvarnik (v njem Majcen izraža sebe) besedo. Na Majcna je močno vplival Guardini, ki trdi, da:

... svet ni izšel le iz moči, a tudi ne le iz mišljenja, ampak iz govora. Tvorbe sveta so besede, s katerimi Bog - Stvarnik izreka svojo smiselno polnost v končnost; pri tem je Bog na poti, da poišče tistega, ki bi jih razumel in bi prek njih stopil z Govorečim v razmerje 'jaz-ti', v razmerje ustvarjenega od Stvarnika. (Majcen 2001: 88)

To dramo je Majcen sicer končal s sporočilom, da množica ne razume sporočila Stvarnikovih besed.

Besedo in jezik je imel Majcen v celoti tudi za natančno merilo vrednosti in nevrednosti literatovega dejanja: $z$ besedo se literat ali preorje v samosvoj umetniški lik ali pa se zmaliči v besedarsko spako. Prvo se doseže z doživeto in duhovno besedo, zanjo pa si mora prizadevati, ker nič resnično živega ne pride v literarno delo že z besedo samo po sebi. Duh jezika mora ukresati iskro! (Zadravec 1990: 25). V pismu Izidorju Cankarju (št. 2) je petindvajsetletni Majcen zapisal ostre vrstice proti tistim, ki »še niso ene noči prečuli v mislih, niti enkrat začutili praznost besede in /.../ zdvomili o vrednosti pisanja (Majcen 2001: 19). Sam je pisal z naporom. Štiriindvajsetleten je navajal v pismu Joži Lovrenčiču misel Karla Krausa: »Kaj je tovarniška nesreča proti bolečinam ob porajanju misli? Dnevom lahkotnega izražanja sledijo dnevi, ki se jih bojim, kajti kar sem zapisal z lahkoto, bom moral z veliko težavo popraviti, z veliko žrtvijo, da bom lahko predal strani naprej.» 
Majcen je svoje ideje pretvarjal v besede z veliko težavo. »Črte v rokopisu naj Te ne motijo: imam slabo navado, da nikoli nisem zadovoljen, « je napisal v pismu Francetu Koblarju (št. 6) (Majcen 2001: 83). Kot ugotavlja Goran Schmidt, je nekatere drame napisal tudi v desetih inačicah.

V drami Bogar Meho in Marija Meho izpoveduje:

Umetnik ne more ostvariti podobe, ki jo v sebi nosi, na ukaz prvega osla, ki zariga. Kaj veste vi, kaj je to, podoba v dušit? To peče, to žge, to se pretvarja in presnavlja vbolečinah - v krčih, ki vijo telo in dušo, se oblikuje in se ne zobliči nikoli. Obraz imaš pred seboj, poteze nebeško mile, senco pred očmi, pod vejicami senco sence - ko pa nastaviš dleto in dvigneš bat, so sanje ugasnile. In zopet se ti prikaže in zopet se ti nasmehne obraz iz teme. Že misliš, da ga imaš, že upaš, da te bo dleto ubogalo. Nastaviš, udariš - in je krivo. Krivo ali nekrivo - ne zaupaš si več, ko si si trenutek prej še zaupal. Zato pa pravim: Ne moreš uliti lika, ki ti v duši trepeta, da ga uliješ, če ni čas za to. (N. d.: 406)

Bogar Meho šele ob koncu življenja doživi polnost vizualnega izraza - videnje Marije. Šele smrt odvzame navideznost in odpre videnje popolnosti, kot izrazi to v črtici Trenutek življenja - zapisek zasutega rudarja: »Do mozga se gledam in ne morem izraziti poslednjega. Snemite kožo z lic, meso s kosti, dajte prosto pot svetlobi ...« (n. d.: 112). V iskanju besede je Majcen izražal strah in dvom o smiselnosti: kako naj izrazi, materializira, kar presega zemeljsko. Noben izraz ne more zadostno, kaj šele enakovredno predstaviti »podobe, $k i$ jo v sebi nosi«.

\section{Iskanje besede}

Po vendarle besede so. Celo Neizgovorljivi je postal Beseda. Poiskati je treba izraz, besedo, ki bo prebudila življenje in po njej bo človek postal kakor Stvarnik, razlaga v svoji drami Revolucija.

Stvarnik: Tedaj - (S kazalcem v zraku, zlog za zlogom). Treba je najti besedo, ki bo vredna življenja, več vredna od življenja ... vsakega življenja. Izreci jo, pa bo življenje rešeno. Ali razumeš to skrivnost?

Vanja: Pa to so besede.

Stvarnik: Besede so ... v začetku je bila beseda. Pred vsem življenjem je bila beseda. Iz nje je vse rojeno, z njo vse umre. Samo, kje jo najti ... in katera je? (N. d.: 112)

Stanko Majcen je verjel, da je našel sporočilo, sedaj je iskal besedo. Vedel je, da bo ostal nerazumljen, pa vendar je govoril, ustvarjal, saj bo morda njegova (Stvarnikova) beseda $v$ nekom postala življenje v poslanstvu odreševanja niča: blata, mlake ...

Svoj pristop k dramskemu ustvarjanju je opisal v pismu Marji Boršnik (št. 15): "Zravnal sem linijo do konca - drama, če naj bo drama, mora biti dosledna do konca - komaj pet besed, odločilnih seveda, sem vstavil na pravih mestih, pa je ideja tu« (Majcen 2001: 168). Ko je bil urednik Zore, je nastopal proti besedičenju. Ko je ocenjeval Bevkovo besedovanje, je napisal Joži Lovrenčiču: 
Saj sem Ti, upam dokazal na tisti dolgi litaniji, da rabi mesto enega tri stavke. To je eno, drugo pa je, da naj študira jezik. Če sem jaz v Gradcu kedaj koli v tem oziru pretiraval, in pretiraval sem, sem to storil namenoma. Preveč jezikovne tehnike ni namreč nam prav nič ne škodilo, ker je imamo troho malo. Da od gole tehnike ne moreš živeti, veš sam. Kako zelo drugače pa izgledaš, če znaš povedati, kar misliš, sijajno, lehkotno, si izkusil že neštetokrat. Bevk naj se omeji, kondenzira. (N. d.: 37)

Najti besedo je neizmeren napor in zahteva jezikovno vedenje in iskanje. $\mathrm{V}$ drami Revolucija:

Vanja: Ne trudi se, oče ... se pravi, išči jo! Če si se po tridesetih letih nenehnega pisanja in fabriciranja knjig dokopal do te modrosti, jo boš tudi našel, tisto besedo.

Stvarnik: Ti ne veruješ vame.

Vanja: Rekel sem. Dokler pišeš, verujem. Toda zdaj ni čas pisanja. (N. d.: 113)

Veličina Stanka Majcna, obenem pa tudi njegova tragičnost je v tem, ker bo iz vsega nastala le knjiga, medtem ko okrog njega "poginja ljudstvo« (n. d.: 84). Ni se zmogel »demostrativno priključiti vrsti« (n. d.: 84), ostajal je samotar in iskal besedo, ki bo močna, ker bo Beseda sama njegovo orožje.

V drami Čudež pravi duhovnik Martin Mareni:

Ti veruješ vame, to je lepo. A ne v mene moraš verovati, temveč v njega, ki govori iz mene, iz mojih besed. Beseda in človek, to je dvoje. Glej, jaz sem truden nocoj, komaj pol človeka sem, v tvoji roki je moje življenje. A beseda, ki jo govorim zmerom in povsod, je vedno enako močna. Ta ni trudna nikdar, ne potrebuje nikdar podpore ... (N. d.: 248)

Besede so, vendar se zastavlja vprašanje o njihovi učinkovitosti na množico. V koncu drame Revolucija je Majcen opisal popolno neučinkovitost, napačno razumljenost besed. Ljudje slišijo, kar hočejo, kar so naučeni slišati. V tem pa je tragičnost Majcna in njegove besede, ki se ni udejanjila.

\section{Ali je sin Vanja našel besedo, ki jo išče oče Stvarnik?}

Ob tem vprašanju moram navesti dva odlomka iz drame Revolucija.

Prvi odlomek so besede slovesa očeta Stvarnika od svojega na smrt obsojenega sina Vanje:

Nisem ti več oče, prijatelj sem ti. Oče je malo, prijatelj je več. Ali veruješ vame? I.../ (S kazalcem v zraku, zlog za zlogom.) Treba je najti besedo, ki bo vredna življenja. Več vredna od življenja ... vsakega življenja. Izreci jo, pa bo življenje rešeno. Ali razumeš to skrivnost? I.../V začetku je bila beseda. Pred vsem življenjem je bila beseda. Iz nje je vse rojeno. /.../ Samo kje jo najti ... in katera je? (N. d.: 112-113)

In drugi odlomek, ko Vanja raztrga list z izjavo, v kateri bi podpisal podreditev družbenemu. Dr. Štrucar meni, da je Vanjevo dejanje tista beseda, ki jo išče njegov oče.

Treba je najti besedo, je rekel oče, ki bo vredna življenja. Več vredna od življenja ... vsakega življenja, pa bo življenje rešeno. Oče ni vedel za to čečkarijo in vendar je pogodil. Nehote pogodil. Ni vrag, če to ni bila tista beseda ... (N. d.: 114) 
Vanja na to molči. Te besede bi lahko izrekel sam. Vendar je njegova beseda njegovo osebno dejanje odvrnitve od pogodbe $\mathrm{z}$ družbenim in vstop $\mathrm{v}$ dejanje osebnega ljubezenskega odnosa s Sonjo (ne le odnosa z njo, po ljubezni do nje Z vsem živim), ki ga po njej vodi v dno družbe, v bolečino in smrt in po smrti v življenje, kot izpove Vanja na začetku prvega dejanja (n. d.: 64).

Ne pisana beseda Očeta - Stvarnika, udejanjena beseda Sina - Vanje (»in beseda je človek postala«) v času in prostoru, v konkretno družbenem, je tista, ki nenehno nagovarja: »Mladenič je bil rojen za čase, ki šele pridejo. /.../ Vanja Stvarnik pa ni od danes. Od zdavnaj je in spet se bo vrnil čez sto let.« (N. d.: 117)

\section{V sinu udejani vstop v nično točko}

V drami Profesor Gradnik pripoveduje:

Tam za tistim oknom, lejte - v mraku je opaziti eno samo razsvetljeno okno - tam za tistim oknom leži žena $v$ neznanskih mukah, da da življenje bitju, ki te reši vsega zlega. Ni veliko, ni razumno, jedva se zaveda, da živi. A tvoja kri je, tvoja duša, toplo se ti ovija krog srca. V neizprosno samoto tvoje borbe, tvojega trpljenja posije obraz, odtis tvojega obraza, le stokrat mlajši, milejši, toplejši. Za vsak tvoj padec obetajoč vstajenje, za vsako razočaranje srečo, za vsak obup novo silo, novo sladko moč ... Gorak obraz v pustinji ledu in snega: kako te pozdravi! Sam si bil, proklet si bil, sojen na vekomaj-zdaj nisi več! Poglejte mene in tisto okno poglejte: milost me je obsvetila, živel bom! (N. d.: 75)

Majcen se je pred družbo čutil za »revolucijo« nemočen, ves bolehen od življenja. Bil je sposoben le besedovati. Življenje samo pa je močnejše, je najbolj izpovedna knjiga. Policijski narednik Carneri pravi o Kasiji: »Naivna je in vendar govori njeno življenje knjige« (n. d.: 45). V isti drami srečamo časnikarja Erika Mülerja, ki »piše knjige in skrbi za navdušenje» (n. d.: 41). Ta časnikar je sicer zaročen s Kasijo, a ona se spogleduje z drugim moškim. Poljub velja drugemu (n. d.: 11), ob katerem zaznava, da bo sposoben vstopiti v dejanje. Ko tega zaradi podružbljenosti ne stori, mu očita: »Izkusila sem. Vi si niste upali z menoj na tisto pot. Zavoljo ljudi, zavoljo sveta si niste upali. Najti sem morala Mülerja. Vidite, to sem izkusila.« (N. d.: 51). Najde Mülerja, torej nekoga, ki samo spremlja, opazuje in piše, ne zmore pa vstopiti v ponoreli ljubezenski odnos, ki speljuje po nični točki v novo življenje.

To, česar Müler, pravzaprav Stanko Majcen, ni zmogel, je vnesel v sina: v mladostni ogenj, v moč njegovega ljubezenskega odnosa (poljuba); to pomeni sposobnost za tveganje, za dejavni korak v nično točko. V Revoluciji ugotavlja Stvarnik:

Mladina je neupognjena, pa čeprav upogljiva /... jeder les, ki prenese težo. Kar na dan z zahtevki, ne bodo krivični. Pretirani bodo - pa saj smo mi tu, da jih umerimo po potrebah. Veseli me, da se je Vanja v usodnem trenutku postavil na vidno mesto ... Nikar se ne smejte, borci, ne šalim se! Sicer imamo dandanašnji vsak glavo v zanki, toda brez tveganja ni življenja. Prav tveganje je tisto, kar miče; kar dosežeš, vselej razočara ... (N. d.: 68) 
Vendar pa tudi smeri za korak tveganja osvetlijo besede. Ko Vanja čuti, da mora narediti ta korak, prosi očeta za določitev smeri: "Poti naravnost me uči, oče, samo poti naravnost, druge nobene hoditi nočem. /... Dejanja se mi hoče, dejanja, ti večni teoretik. Vse moje bitje kriči po dejanju. Pokaži mi ga, če ga imaš! « (n. d.: 84). Izkaže se, da je oče v svojem iskanju besede nemočen. Skuša se opravičiti, da ostaja le pri besedah: »Dejanje je lahko tudi prazen zvok« (prav tam). In ko v nadaljevanju zatrdi, da je najmodrejše zajeti v besede vse, kar se dogaja, mu sin očita: „... in bo knjiga. - Krog mene pa poginja ljudstvo« (n. d.: 84).

Tragičnost Stanka Majcna je v tem, da ni mogel dejavno vstopiti v nično točko; ostajal je le analitik, "glasnik duha« (prav tam), Vanji - sinu pa ni bilo za teorijo. »Storil bom, kar je storiti treba, makar me oznamenijo za Efialta« (n. d.: 85).

Majcen je vedel, da je bila sinova odločitev - izstop iz podružbljenega v nično točko - pravilna, pa je vendarle izražal bolečino ob privolitvi v sinovo odločitev. Vanja bi moral, da ohrani življenje, da ga ne umorijo, podpisati izjavo, v kateri bi zanikal svoje ideale, moral bi ostati v splošno podružbljenem. Tega seveda ni storil. Besede je potrdil z življenjem.

Stanku Majcnu so umorili sina. V Materah pravi: »Če bi takle fant, ko pade, vedel, koliko src podre pod seboj, bi se dvignil. Dvignil bi se in planil« (n. d.: 268). »Kakor, da se je od mene utrgalo pol jaza, se je od mene odtrgal ta sin. Nisem več jaz, odkar se je to zgodilo, izjavlja v Revoluciji (n. d.: 120).

Po Vanjevi (sinovi) smrti dobi Stvarnik (Majcen) moč, pogum - ni več sam. To, kar je udejanjil sin, postaja moč za njegovo življenje.

Stvarnik: Bojim se jih! Imam nekoga, ki je z menoj in ki me ne zapusti. Sam slepec-pa se bom slepcev bal, ko je nad vsemi nami svetloba? Vanja, nebeški vojščak, dvigni svoj meč, da bomo videli, kje smo! (N. d.: 122)

Stvarnik: Tako mi je, da bi jim povedal ... Kakor mi je pri srcu, povedal enkrat za vselej, pa naj me potem križajo, če me hočejo. Mostove za seboj sem podrl-lej ta koš! - nazaj ne morem več. Naprej bi rad, če bi mogel. In morem ... Vanja mi kaže pot. (N. d.: 123-124)

Majcen je uspel po bolečem izkustvu - sinovi smrti prerasti nasprotje med besedo in dejanjem; to je glavna ideja Revolucije, piše v pismu Marji Boršnik (št. 65) (Majcen 2001: 234). Seveda je to uspel le v drami. V stvarnosti pa je do konca svojega življenja ostal družbeno uglajen človek. Kakor koli, vredno je, da ga v njegovem bogatem zapisanem sporočilu naš čas bolj ovrednoti. Morda pa bo takrat njegova beseda prebudila in vzpodbudila tisto, kar je sam želel, pa ni zmogel: učinkovita dejanja v premagovanju trpljenja nemočnih.

\section{LITERATURA}

Alenka GLAZER, 1990: Majcnova otroška poezija. Majcnov zbornik. Ur. Goran Schmidt. Maribor: Obzorja. 53-62. 
Romano GUADINI, 1991: Svet in oseba. Celje: Mohorjeva družba.

Taras KERMAUNER, 1990: Cesar Janez. Majcnov zbornik. Ur. Goran Schmidt. Maribor: Obzorja. 112-143.

- -, 1992a: Majcnova dramatika 1. Ljubljana: Lumi.

- -, 1992b: Majcnova dramatika 2. Ljubljana: Lumi.

France KOBLAR, 1939: Majcen Stanko. Slovenski biografski leksikon. Ljubljana: Zadružna gospodarska banka 2/5, 24.

Gregor KOCJAN, 1990: Majcnova kratka pripovedna proza. Majcnov zbornik. Ur. Goran Schmidt. Maribor: Obzorja. 86-95.

Stanko MAJCEN, 1939: Uprava v pravni državi. Spominski zbornik Slovenije ob dvajsetletnici kraljevine Jugoslavije. Ur. Jože Lavrič, Josip Mal, France Stele. Ljubljana: Jubilej.

- -, 1971: Bogar Meho in Marija. Celje: Nova Mladika.

- -, 1981: Ženin na Mlaki. Dialogi, 909-931.

- -, 1994-2001: Zbrano delo (1.-8. knjiga). Ur. France Bernik in Goran Schmidt. Ljubljana: DZS.

- -: Brez sveče. Rokopis.

Denis PONIŽ, 1990: Stanko Majcen, pesnik apokalipse. Majcnov zbornik. Ur. Goran Schmidt. Maribor: Obzorja. 43-51.

Dimitrij RUPEL, 1990: Dvorni pisatelj zgubljenega kraljestva. Majcnov zbornik. Ur. Goran Schmidt. Maribor: Obzorja. 153-164.

Goran SCHMIDT, 1990: Majcnov zbornik. Maribor: Obzorja.

--, 1997: Opombe k peti knjigi v Zbranih delih Stanka Majcna (285-521). Ljubljana: Državna založba Slovenije.

Zorko SIMČIČ, 2000: Srečanja z Majcnom: Buenos Aires-Maribor: 1961-1970. Ljubljana: Nova revija.

Bernard STRITIH, 1996/97: Razvoj prakse in teoretičnih konceptov skupinskega dela. Gozd Martuljek: Ad fontes d. o. o.

Stefan ZWEIG, 1958: Včerajšnji svet, spomini Evropejca. Ljubljana: Cankarjeva založba.

\section{THE SUFFERING OF THE INNOCENT AND THE SEARCH FOR WORDS OF SOLU/SALVA/TION IN THE PLAYS OF SLAVKO MAJCEN}

This article examines the issue of the suffering of the innocent, and the attempts to find salvation in the plays of Stanko Majcen. Suffering was, for this exceptional Slovenian playwright, a special problem which touched him deeply. Spared from the harshness of life in many ways himself, he was continuously confronted with the misery and cold 
ignorance of those who are saved from it. The suffering of the helpless moved him too much to stay silent and not to protest. In the one-act play entitled Profesor Gradnik (Professor Gradnik) we read: "Allow me to use this opportunity to remark upon something I cannot silently pass over. Misery: starvation, poverty in a big city - is a physical pain, no doubt. But this is not the main point. The crucial point is what in this misery remains outside your awareness. I mean the blood flows out, the principles lose ground, everything freezes hanging in the air. With all your passion you throw yourself into various theories, you interpret the views on which no common sense can ever rest. You exaggerate with the understanding gained and you unnecessarily get excited about discoveries that are none of your business. Revolution, revolution, revolution is crawling all over your head." (71). This internal revolt at the confrontation with suffering is not easy to recognise in Majcen's refinement; however, it is clearly expressed in his plays, in his understanding of the redemption of nothingness. Majcen was not a personality to demolish and abandon social institutions. On the contrary, he took part in them. However, he did allow himself to perceive himself in his plays (and indeed, perhaps only in his plays) in a different light, and he seriously wondered what his abilities were, how he could create and represent himself. Words became his weapon. He wanted to break up the rigid falseness of the time with his ideas. However, he never came to terms with the fact that words were his only weapon. In his plays he demonstrates their inefficiency, as they often achieve an opposite effect on the crowds from the intended one. Majcen succeeded only after a painful experience, with the son's death in the play Revolucija (Revolution), the conflict between words and actions is overcome. But then again, he managed to do this only in a play. In real life, he remained a socially refined person till the end of his life. Nevertheless, it is time for his work to receive the recognition it has earned. Perhaps now his words will encourage and enable what he wished, but failed, to achieve: effective action to overcome the suffering of the helpless. 